\title{
ARTICLE
}

\section{The Impact of COVID-19 on the Use of Academic Library Resources}

Ruth Sara Connell, Lisa C. Wallis, and David Comeaux

\section{ABSTRACT}

The COVID-19 pandemic has greatly impacted higher education, including academic libraries. This paper compares the use of library resources (including interlibrary loan, website and discovery tool pageviews, database use, patron interactions, etc.) at three university libraries before and after the pandemic. The latter part of the 2019 and 2020 spring semesters are the time frames of focus, although two control time frames from earlier in those semesters are used to determine how the semesters differed when the coronavirus was not a factor. The institutions experienced similar patterns of use across many metrics.

\section{INTRODUCTION}

The year 2020 will be remembered as the year of the novel coronavirus (COVID-19). Around the world, hundreds of thousands of people died from the disease, schools and businesses shut their doors, wearing masks in public places became commonplace, and unemployment soared. ${ }^{1}$ Everyone and everything changed in ways large and small, and libraries were no exception.

This study measures changes in use of library resources during time frames of COVID-19 closures at three different institutions: Louisiana State University, Northeastern Illinois University, and Valparaiso University. These three universities vary in size (large to medium), control (two public, one private), basic Carnegie classification (Doctoral-Very High Research, Master's, and Doctoral/ Professional), and setting (two primarily non-residential and one highly residential). ${ }^{2}$ Despite their differences, these institutions experienced similar patterns of use across many categories.

Key findings:

- The pandemic affected the three institutions studied on a continuum, with the least impact at the largest school, and the biggest drop in use seen at the smallest school.

- Use of all three libraries' websites as well as the discovery tools/catalogs and major databases decreased during the COVID time frame.

- All three libraries experienced an increase in virtual communication.

\section{BACKGROUND}

\section{Louisiana State University}

Louisiana State University (LSU) is the flagship institution of Louisiana and is one of only 22 prestigious universities nationwide holding land-grant, sea-grant, and space-grant status. The main campus is in Baton Rouge, has the Carnegie basic classification "Doctoral Universities: Very

Ruth Sara Connell (Ruth.Connell@valpo.edu) is Professor of Library Science \& Director of Systems, Valparaiso University. Lisa C. Wallis (l-wallis@neiu.edu) is Associate Dean of Libraries and eResources \& Systems Librarian, Northeastern Illinois University. David Comeaux (davidcomeaux@lsu.edu) is Systems and Discovery Librarian, Louisiana State University. (c) 2021. 
High Research Activity," is primarily non-residential, and has a student full-time equivalent (FTE) of about $30,000 .^{3}$

LSU Library is the university's main library and a center of campus life for both students and faculty, and it houses approximately three million physical items (print books, media, and serials). ${ }^{4}$ Before the onset of COVID-19, LSU Library was open 24/5 (24 hours Sunday-Thursday) plus weekend hours, with a 24/7 schedule during finals. As of July 30, 2020, it had 100 employees, of which 39 were librarians.

LSU Library staff, like all nonessential LSU staff, last reported to work in-person on Monday, March 16. The previous day, the state's governor ordered a statewide stay-at-home order, restricting events and closing venues. That Monday, library IT employees hurriedly assisted other staff in preparing to work remotely. Near the end of the day, the university's president sent an email asking all employees to work from home until further notice. Classes were canceled for the week to allow instructors to prepare for remote teaching. The following week, March 23, was the beginning of spring break. Classes resumed online-only on March 30. The libraries remained closed through the duration of the spring semester. Despite the closure, the libraries continued to serve patrons. Librarians continued to assist students through email and Zoom-based sessions. The catalog and discovery systems remained available, and staff continued to fill article and book chapter requests through interlibrary loan and document delivery.

\section{Northeastern Illinois University}

Northeastern Illinois University (NEIU) is a public, comprehensive, multicultural university located on the north side of Chicago. It has an enrollment of approximately 7,000 students in undergraduate and graduate programs among three colleges: Arts and Sciences, Education, and Business. While currently classified in the "Master's Colleges and Universities: Larger Programs" category, NEIU is undergoing a major enrollment shift due to the state of Illinois' failure to provide a budget during the period 2015-2017 and, now, the COVID crisis. ${ }^{5}$ The spring 2019 FTE was 4,644 (83\% undergraduate), while in spring 2020, FTE was 4,404 (80\% undergraduate). The campus is primarily a commuter campus.

The NEIU Libraries offer library services at three locations in Chicago. Altogether, the three libraries house approximately 500,000 physical books, media, and serials. ${ }^{6}$ In spring 2020, the NEIU libraries employed 12 people in positions requiring an MLS-including the Dean and Associate Dean of Libraries-and 18 staff. The main library is typically open 92 hours per week.

NEIU's spring break typically falls at the same point in the semester every year, with the spring 2020 break scheduled to begin on Saturday, March 14. The week prior to spring break, NEIU's president announced that the break would be extended by an extra week to allow instructors to move instruction to alternatives from face-to-face teaching. The NEIU Libraries closed its doors on Wednesday, March 18 at 6 p.m., and library faculty and staff began working from home. The libraries were able to offer continued reference and instruction by chat, email, phone, and Google Meet and to fill article and book chapter requests electronically. No physical materials were available, as the statewide delivery system supporting borrowing among academic libraries stopped its services on March 16. Alternative instruction resumed on Monday, March 30 for all students. 


\section{Valparaiso University}

Valparaiso University (Valpo) is a private, not-for-profit, highly residential, four-year university in northwest Indiana. Its Carnegie basic classification is “Doctoral/Professional Universities," although it serves a largely undergraduate student population (90\% of FTE in spring 2020). The graduate programs serve fewer than 500 students. During the time frame of this study, Valpo's FTE ranged from 3,449 (spring 2019) to 3,147 (spring 2020). ${ }^{7}$

There is one library on campus. The Christopher Center for Library and Information Resources has approximately 450,000 items in its print collection. ${ }^{8}$ During the fall and spring semesters (excluding breaks), the library is open 113 hours per week. As of fall 2020, the library employed 19 people: 10 librarians (including the dean) and nine staff members. This is four fewer positions than before the pandemic; due to COVID-19 funding cuts, three staff members were laid off and one open librarian position was eliminated.

Valpo is unusual in that it has a two-week spring break which always falls on the first full two weeks in March. In 2020, spring break coincided with the burgeoning COVID-19 crisis. During the second week of spring break, campus administration announced that campus would remain open, but classes would go online immediately following the break, starting Monday, March 16. On March 16, the Christopher Center Library moved to reduced hours (open 67.5 hours per week). As the fallout from the pandemic rapidly unfolded, hours were further reduced four days later. At the close of business on Tuesday, March 24, in accordance with the state of Indiana's stay-at-home order, the physical building closed, although library faculty and staff continued to work from home.

\section{LITERATURE REVIEW}

\section{Preparing and Responding to Pandemics and Other Disasters}

Libraries have long understood the need to prepare for disasters and have chronicled their struggles with disasters both natural and man-made. Library collections have been lost due to fires and floods, and libraries have been forced to drastically alter their service models in response. The literature on this topic includes surveys of libraries regarding their emergency preparedness, advice on preparing disaster recovery plans, and recovering or replacing lost collections. ${ }^{9}$

One particularly prescient article describes the work done at the University of Minnesota's School of Public Health. ${ }^{10}$ Two librarians joined a task force to prepare the school to function through an influenza pandemic. They focused on two scenarios. One was the onset of a pandemic midsemester, forcing schools to close for weeks or even through the duration of the semester. The other was an even longer (9- to 18-month) school closure. Both scenarios included implementing social distancing practices now familiar to us all. The task force provided many recommendations to enable continuity of online teaching in the event of a pandemic, but none dealt specifically with libraries.

\section{Resource Use during Building Disruptions}

Previous studies have studied the impact on the use of library resources during building disruptions, generally due to renovations. In the studies reviewed, these libraries moved to temporary locations and still had some physical space available to students. This differs from the complete closure experienced by most libraries due to COVID-19. Typically, library services and resources are used less when normal building operations are disrupted, but there are exceptions. 
In 1999, the library at Eastern Illinois University closed for 31 months. Library services were relocated elsewhere. Overall, the library experienced a "sharp drop in the use of library resources and services," although one bright spot of growth was in interlibrary loan use, which went up by $16 \% .{ }^{11}$ However, the authors note that this increase may be due to patrons placing requests for items owned by EIU that were difficult to access.

McNeese State University in Louisiana started a multiyear library renovation in 2012, during which the library's personnel, services, and a small subset of the collection were relocated to a ballroom in the student union. A 2016 article discusses effects on library services half-way through the disruption. In reviewing the literature, the author found, "the longer students and faculty are not allowed access to the library building, the more usage statistics such as circulation, interlibrary loan (ILL), and instruction decrease."12 McNeese experienced a 22\% decrease in interlibrary loan requests (borrowing and lending), a 51\% decrease in the use of e-books, and a $62 \%$ decline in reference transactions. The author noted that "Nearly every library service experienced a precipitous decline."13

Pepperdine University bucked the trend of sharp decreases during their 2016-2017 renovation. They experienced a dramatic increase in the number of interlibrary loan requests, both for borrowing (33\%) and lending (375\%), likely related to their decision to join RAPID-ILL at the beginning of the renovation. Conversely, there was a slight decrease $(10 \%)$ in borrowing from the California statewide consortium. Pepperdine's e-book usage remained fairly steady and actually increased 3\% during the disruption. As expected, their in-person questions decreased while in a temporary facility, although chat and email reference questions increased by $30 \%{ }^{14}$

\section{COVID-19 Impact}

Though the coronavirus was first discovered to have reached the United States in January 2020, it was not until late February that American colleges and universities began to implement travel restrictions for students and staff and to develop plans for potential closure..$^{15}$ By early March 2020 the US Department of Education had developed guidelines for the coronavirus' impact on distance learning and financial aid. ${ }^{16}$ The topic was also the subject of numerous articles on higher education websites such as the Chronicle of Higher Education and Inside Higher Ed.

In March 2020, when the impact of COVID-19 began to reverberate around the United States, virtually all libraries closed. ${ }^{17}$ The American Library Association (ALA) conducted a survey of libraries of all types in May and reported that the majority of academic libraries had already lost funding, or anticipated losing funding within the next year, for staff, new hires, professional development, print collections, programs, and services. ${ }^{18}$ The press release for the ALA survey stated that "survey respondents shared leaps in the use of digital content, online learning, and virtual programs." ${ }^{19}$ However, a review of the survey instrument reveals that no questions were asked about use of these resources, so it is unclear where this assertion comes from. ${ }^{20}$ The survey included opportunities to leave comments, so it may be that the leaps in use mentioned in the ALA press release is anecdotal. Although libraries have never faced a global pandemic in modern times, previous research indicates library building disruptions generally reduce use, not cause it to increase as described in the press release.

Academic libraries were among the last facilities to close on many campuses, as they were viewed as essential for students. ${ }^{21}$ However, as early as the week of March 9, 7\% of academic libraries reported that they had stopped circulating physical materials. In addition, building and face-to- 
face reference desk staffing began to be scaled back, with $28 \%$ of reporting libraries doing no faceto-face reference by the end of that week. ${ }^{22}$ Complete closure of academic library physical facilities became the norm by mid-March, with vocal advocacy for that measure expressed by both the American Library Association and the Association of College and Research Libraries. ${ }^{23}$

Apart from library instruction, the coronavirus did not so much force academic libraries to move online as to temporarily suspend physical and in-person services. By 2020, provision of online services-including book, article, and media circulation and email and chat reference-was nothing new for libraries. Recent years have seen increased migration to cloud-based systems, eliminating the need for library work to be done using specific client software on library staff computers. Academic libraries and vendors alike promoted the ability of their institutions and computer systems to handle the COVID-19 crisis with minimal disruption. ${ }^{24}$

The International Coalition of Library Consortia (ICOLC) issued a statement on March 13, 2020 , asking vendors to lift many of the usual licensing restrictions and opening access to the 391 million students affected by school and library shutdowns. ${ }^{25}$ Publishers and vendors quickly began to remove paywalls between users and their online collections, either for free without library mediation or upon library request. ICOLC followed up by starting a comprehensive list of these materials on March 16, 2020.26

Despite increased access to online collections, library resource use was disrupted. No matter how many services can be offered online, plenty of students and faculty still use traditional items such as print books. Given the circumstances of COVID-19, with sudden and lasting limits on access to physical materials and space, academic libraries began to promote online equivalents of these, such as the HathiTrust Emergency Temporary Access Service (ETAS), which Penn State reported offered "reading access to more than $48 \%$ of the Libraries' print collections." ${ }^{27}$ Upon seeing the collected mass of print books students returned prior to leaving campus due to COVID-19, librarian Nora Dimmock of Brown University's John Jay Library identified the need to move "more intentionally" to e-books over print books in future purchasing decisions. ${ }^{28}$

\section{METHODOLOGY}

In order to determine whether the COVID-19 pandemic affected use of library systems and resources, the researchers compared usage statistics from a COVID-affected time frame in 2020 to the same time frame in 2019. These will be called the COVID 2019 and COVID 2020 time frames (or COVID time frames collectively).

Because there could be other factors influencing use, such as differences in student FTE between the two years, the researchers also pulled data from control time frames to compare earlier in the spring semesters. These control time frames were unaffected by COVID in both 2019 and 2020. These will be called the Control 2019 and Control 2020 time frames (or control time frames collectively). By including data from the control time frames, we were able to determine whether there were trends affecting usage differences before the pandemic hit. As an example, LSU's catalog pageviews were down $5 \%$ from the previous year during the first part of the semester unaffected by COVID-19. For the latter part of the semester affected by COVID-19, catalog use fell $25 \%$ as compared to the previous year. The control time frame comparison shows that catalog use was already in decline before the pandemic; therefore, some of the $25 \%$ decline is likely due to factors other than COVID-19. The baseline factored difference is $-20 \%(-5 \%+x=-25 \% ; x=$ 
$-20 \%)$. Figures 2, 4, and 6 illustrate the percentage of differences in COVID time frames from determined baselines.

Each of the three researchers determined the control and COVID time frames for their own institutions. Because the academic calendars vary widely between the three institutions, the time frames of study also differ. The absolutes for each institution were:

- The 2019 and 2020 control time frames were the same number of days

- The 2019 and 2020 COVID time frames were the same number of days (but the control time frames were not the same length as the COVID time frames)

- If a time frame from one year contained a special calendar event (e.g., spring break, Mardi Gras holiday, etc.), the researchers made sure the corresponding time frame from the other year also included that event.

Table 1. Dates of institutions' control \& COVID comparison time frames (excluding EBSCO and ProQuest)

\begin{tabular}{|l|l|l|l|l|}
\hline & $\begin{array}{l}\text { Control time } \\
\text { frame 2019 }\end{array}$ & $\begin{array}{l}\text { Control time } \\
\text { frame 2020 }\end{array}$ & $\begin{array}{l}\text { CovID time } \\
\text { frame 2019 }\end{array}$ & $\begin{array}{l}\text { COVID time } \\
\text { frame 2020 }\end{array}$ \\
\hline LSU & $\begin{array}{l}\text { Monday, January } \\
\text { 14 through } \\
\text { Friday, March 8 }\end{array}$ & $\begin{array}{l}\text { Monday, January } \\
\text { 13 through } \\
\text { Friday, March 6 }\end{array}$ & $\begin{array}{l}\text { Monday, March } \\
18 \text { through } \\
\text { Saturday, April } \\
27\end{array}$ & $\begin{array}{l}\text { Monday, March } \\
\text { 23 through } \\
\text { Saturday, May 2 }\end{array}$ \\
\hline NEIU & $\begin{array}{l}\text { Monday, January } \\
7 \text { through Friday, } \\
\text { March 15 }\end{array}$ & $\begin{array}{l}\text { Monday, January } \\
6 \text { through Friday, } \\
\text { March 13 }\end{array}$ & $\begin{array}{l}\text { Saturday, March } \\
16 \text { through } \\
\text { Sunday, May 5 }\end{array}$ & $\begin{array}{l}\text { Saturday, March } \\
14 \text { through } \\
\text { Sunday, May 3 }\end{array}$ \\
\hline Valpo & $\begin{array}{l}\text { Wednesday, } \\
\text { January 9 } \\
\text { through Friday, } \\
\text { March 1 }\end{array}$ & $\begin{array}{l}\text { Wednesday, } \\
\text { January 8 } \\
\text { through Friday, } \\
\text { February 28 }\end{array}$ & $\begin{array}{l}\text { Monday, March } \\
18 \text { through } \\
\text { Tuesday, May 14 }\end{array}$ & $\begin{array}{l}\text { Monday, March } \\
16 \text { through } \\
\text { Tuesday, May 12 }\end{array}$ \\
\hline
\end{tabular}

The primary concern was to ensure that each institution was comparing like time frames to like time frames within its own academic calendar. The variability of institutional calendars means that the data cannot be compared between institutions.

For the major database platforms, the control and COVID time frames differ from the other areas measured due to limitations of the statistical platforms. EBSCO and ProQuest platforms allow reports to be run on full months only; partial month statistics cannot be pulled. For that reason, for the major database platforms alone, the control time frame is January through February, and the COVID time frame is April through May. Because 2020 was a leap year, February 2020 had one more day than February 2019. This means that the 2019 control time frame had 59 days while the 2020 control time frame had 60 days. The extra day could account for an increase in use of approximately $2 \%$.

When evaluating use of database platforms, there are several metrics from which to choose. The authors chose full text downloads (the COUNTER metric known as total item requests) because it is the same across reports. There are different search metrics in platform and database reports, so the authors chose to focus on the consistency of the full text download metric. When considering 
e-resource use during COVID-19, another factor to consider is that many publishers removed some or all of their paywalls as the pandemic began. According to COUNTER, the non-profit organization that regulates standards for usage data:

As a result of this open content, usage may appear to go down during this period. This is because many of your users will be working from home, outside of your institution's IP range and not authenticated. This means that the publishers are unable to attribute this usage to your institution. ${ }^{29}$

The journal platforms (Wiley, Sage, etc.) were more likely to be affected by this consideration than EBSCO and ProQuest, who did not remove paywalls for databases of interest to academic audiences.

The researchers determined which metrics to harvest. The following were selected:

- Main website usage

- Catalog usage

- Discovery Tool usage

- LibGuides usage (Database A-Z lists and guide views)

- Interlibrary loan article requests received (for both lending and borrowing)

- SFX Document Delivery clickthroughs

- EBSCO and ProQuest Total Item Requests (full text downloads)

- Patron interactions (chat questions, research consultations, ask-a-librarian)

The three institutions use different products for discovery tools, chat reference, and interlibrary loan, so reporting mechanisms also vary. However, in general a combination of Google Analytics pageviews and vendors' own reporting systems were used to pull the data.

NEIU Libraries migrated from ILLiad to Tipasa in June 2019, so it was not possible to gather comparable daily statistics for interlibrary loan request comparisons. Since NEIU did not have interlibrary loan data available that compared 2019 to 2020, the SFX report on Document Delivery clickthroughs was used as a proxy measure. When full text of an item is not available in a database, the DocDel clickthroughs indicate that the user went to the SFX menu and then the Tipasa interlibrary loan request page.

Because of various factors, not all data points are available for the three institutions. For example, NEIU is part of the CARLI consortium. It was decided by a CARLI committee a few years ago that Google Analytics would not be used in the shared catalog in order to protect users' privacy, so the catalog usage data point is missing for NEIU. NEIU and Valpo have chat service data; LSU now has chat but did not during the time frames under investigation. When data are not available, they are missing from the tables and results.

\section{RESULTS}

\section{Louisiana State University}

LSU's data present a mixed picture. While the use of LibGuides rose, use of the libraries' website, discovery system, and catalog all declined during the COVID-enforced closure. While downloads through EBSCO increased during the COVID time frame by $30 \%$, that is less than the increase 
during the control time frame (37\%), resulting in a baseline-factored decrease. Interlibrary Loan requests and requests for help from patrons rose considerably.

Table 2. LSU: Use of library resources during control and COVID time frames, 2019 and 2020

\begin{tabular}{|c|c|c|c|c|c|c|}
\hline Measure of use & $\begin{array}{c}2019 \\
\text { control }\end{array}$ & $\begin{array}{c}2020 \\
\text { control }\end{array}$ & $\begin{array}{l}\text { Control } \\
\text { period } \\
\text { change }\end{array}$ & $\begin{array}{c}2019 \\
\text { COVID }\end{array}$ & $\begin{array}{c}2020 \\
\text { COVID }\end{array}$ & $\begin{array}{l}\text { COVID } \\
\text { period } \\
\text { change }\end{array}$ \\
\hline $\begin{array}{l}\text { ILL borrowing \& } \\
\text { DocDel }\end{array}$ & 3,872 & 3,774 & $-3 \% \nabla$ & 2,619 & 3,525 & $35 \% \Delta$ \\
\hline ILL lending & 2,692 & 2,419 & $-10 \% \nabla$ & 1,845 & 2,884 & $56 \% \triangle$ \\
\hline Catalog pageviews & 83,760 & 79,838 & $-5 \% \nabla$ & 54,662 & 41,000 & $-25 \% \nabla$ \\
\hline $\begin{array}{l}\text { Discovery tool } \\
\text { pageviews }\end{array}$ & 432,070 & 407,832 & $-6 \% \nabla$ & 349,558 & 291,093 & $-17 \% \nabla$ \\
\hline $\begin{array}{l}\text { EBSCO total item } \\
\text { requests }\end{array}$ & 59,892 & 81,804 & $37 \% \Delta$ & 49,819 & 64,817 & $30 \% \Delta$ \\
\hline $\begin{array}{l}\text { ProQuest total item } \\
\text { requests }\end{array}$ & 2,783 & 5,575 & $100 \% \Delta$ & 6,002 & 2,859 & $-52 \% \nabla$ \\
\hline $\begin{array}{l}\text { Main website } \\
\text { pageviews }\end{array}$ & 164,329 & 151,090 & $-8 \% \nabla$ & 103,340 & 81,404 & $-21 \% \nabla$ \\
\hline Databases A-Z views & 27,977 & 26,037 & $-7 \% \nabla$ & 20,893 & 19,624 & $-6 \% \nabla$ \\
\hline LibGuides views & 127,191 & 123,783 & $-3 \% \nabla$ & 12,163 & 18,925 & $56 \% \triangle$ \\
\hline $\begin{array}{l}\text { Ask-a-Librarian } \\
\text { tickets }\end{array}$ & 35 & 88 & $151 \% \Delta$ & 17 & 108 & $535 \%$ \\
\hline
\end{tabular}




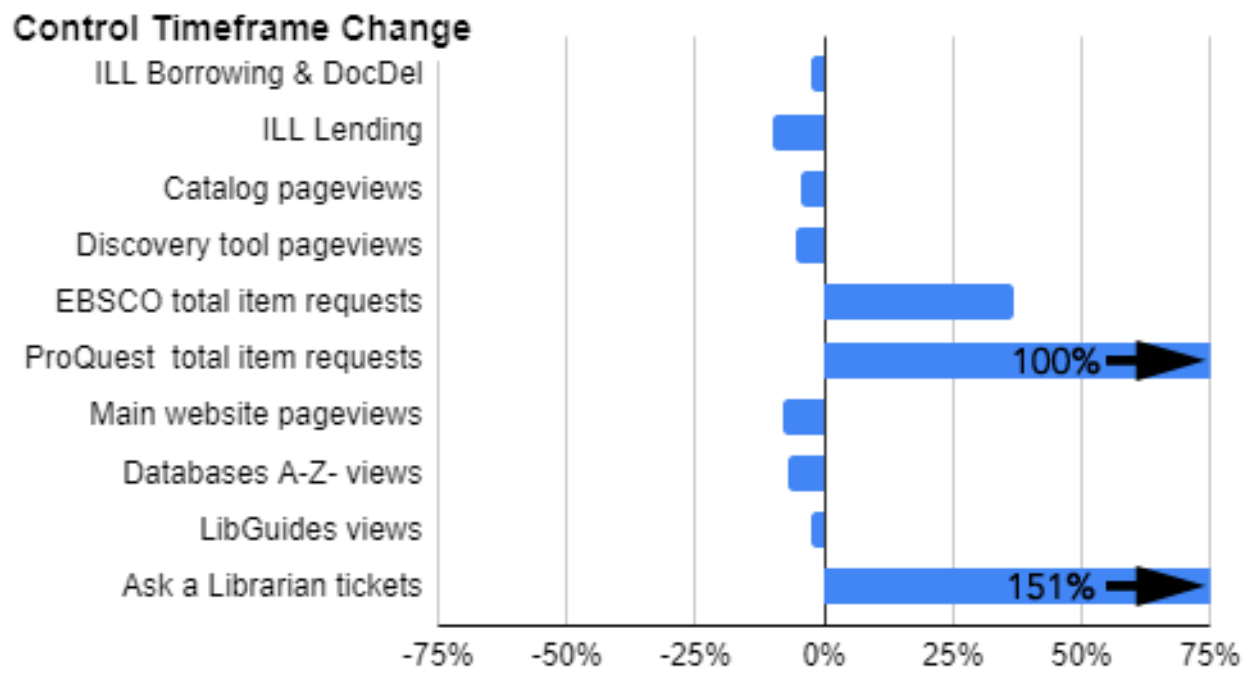

\section{COVID Timeframe Change}

ILL Borrowing \& DocDel

ILL Lending

Catalog pageviews

Discovery tool pageviews

EBSCO total item requests

ProQuest total item requests

Main website pageviews

Databases A-Z- views

LibGuides views

Ask a Librarian tickets

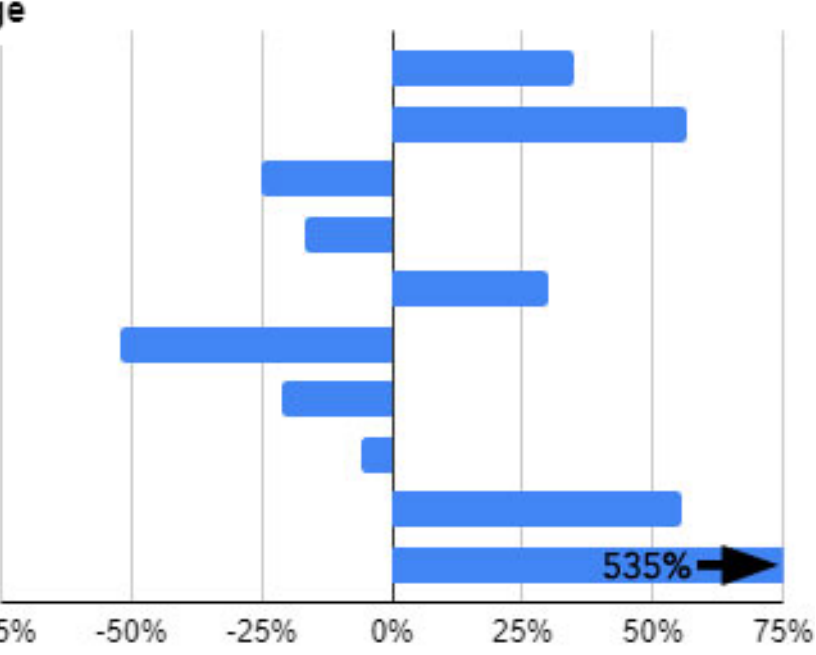

Figure 1. LSU: Change from 2019 to 2020 in both control and COVID time frames (in \%).

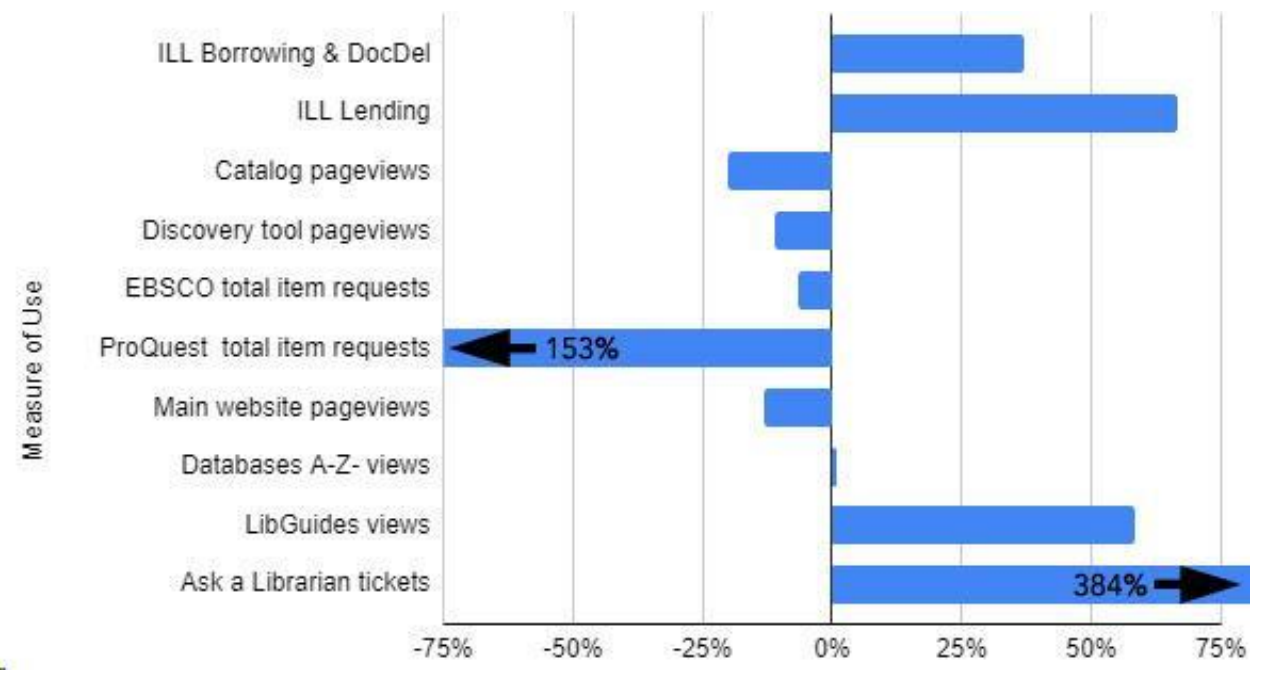

Figure 2. LSU: Percentage of differences in COVID time frames from determined baselines. 


\section{Northeastern Illinois University}

Use of some of NEIU's resources dropped dramatically during the COVID 2020 time frame. However, use of some resources was already lower overall in 2020 than in 2019, even in the control time frame. Illinois has experienced a tumultuous few years, with state universities starting new fiscal years without budgets in 2015 and 2016. This has led to a steady decrease in enrollment at public regional universities, as students sought to attend more stable institutions out of state. ${ }^{30}$ NEIU was hit particularly hard, experiencing a 25\% drop in enrollment between fall 2015 and fall $2019 .{ }^{31}$ So, it is likely some of the decrease in 2020 was due to lower enrollment. Areas that saw growth in COVID time frame 2020 were chat and reference consultations and interlibrary loan clickthroughs from SFX (see table 3).

Table 3. NEIU: Use of library resources during control and COVID time frames, 2019 and 2020

\begin{tabular}{|c|c|c|c|c|c|c|}
\hline Measure of use & $\begin{array}{c}2019 \\
\text { control }\end{array}$ & $\begin{array}{c}2020 \\
\text { control }\end{array}$ & $\begin{array}{c}\text { Control } \\
\text { time frame } \\
\text { change }\end{array}$ & $\begin{array}{c}2019 \\
\text { COVID }\end{array}$ & $\begin{array}{c}2020 \\
\text { COVID }\end{array}$ & $\begin{array}{c}\text { COVID time } \\
\text { frame } \\
\text { change }\end{array}$ \\
\hline $\begin{array}{l}\text { SFX DocDel } \\
\text { clickthroughs }\end{array}$ & 1,864 & 2,728 & $46 \% \triangle$ & 924 & 1,249 & $35 \% \Delta$ \\
\hline $\begin{array}{l}\text { Discovery tool } \\
\text { pageviews }\end{array}$ & 52,435 & 50,310 & $-4 \% \nabla$ & 30,362 & 23,729 & $-22 \% \nabla$ \\
\hline $\begin{array}{l}\text { EBSCO total item } \\
\text { requests }\end{array}$ & 14,525 & 19,704 & $36 \% \triangle$ & 15,785 & 15,452 & $-2 \% \nabla$ \\
\hline $\begin{array}{l}\text { ProQuest total item } \\
\text { requests }\end{array}$ & 7,003 & 5,842 & $-17 \% \nabla$ & 6,895 & 4,898 & $-29 \% \nabla$ \\
\hline $\begin{array}{l}\text { Main website } \\
\text { pageviews }\end{array}$ & 47,085 & 43,215 & $-8 \% \nabla$ & 28,938 & 15,624 & $-46 \% \nabla$ \\
\hline Databases A-Z views & 11,475 & 11,980 & $4 \% \Delta$ & 8,687 & 7,743 & $-11 \% \nabla$ \\
\hline LibGuides views & 7,473 & 7,081 & $-5 \% \nabla$ & 3,317 & 3,282 & $-1 \% \nabla$ \\
\hline Chats & 363 & 306 & $-16 \% \nabla$ & 182 & 213 & $17 \% \triangle$ \\
\hline $\begin{array}{l}\text { Research } \\
\text { consultations }\end{array}$ & 162 & 149 & $-8 \% \nabla$ & 59 & 77 & $31 \% \Delta$ \\
\hline
\end{tabular}



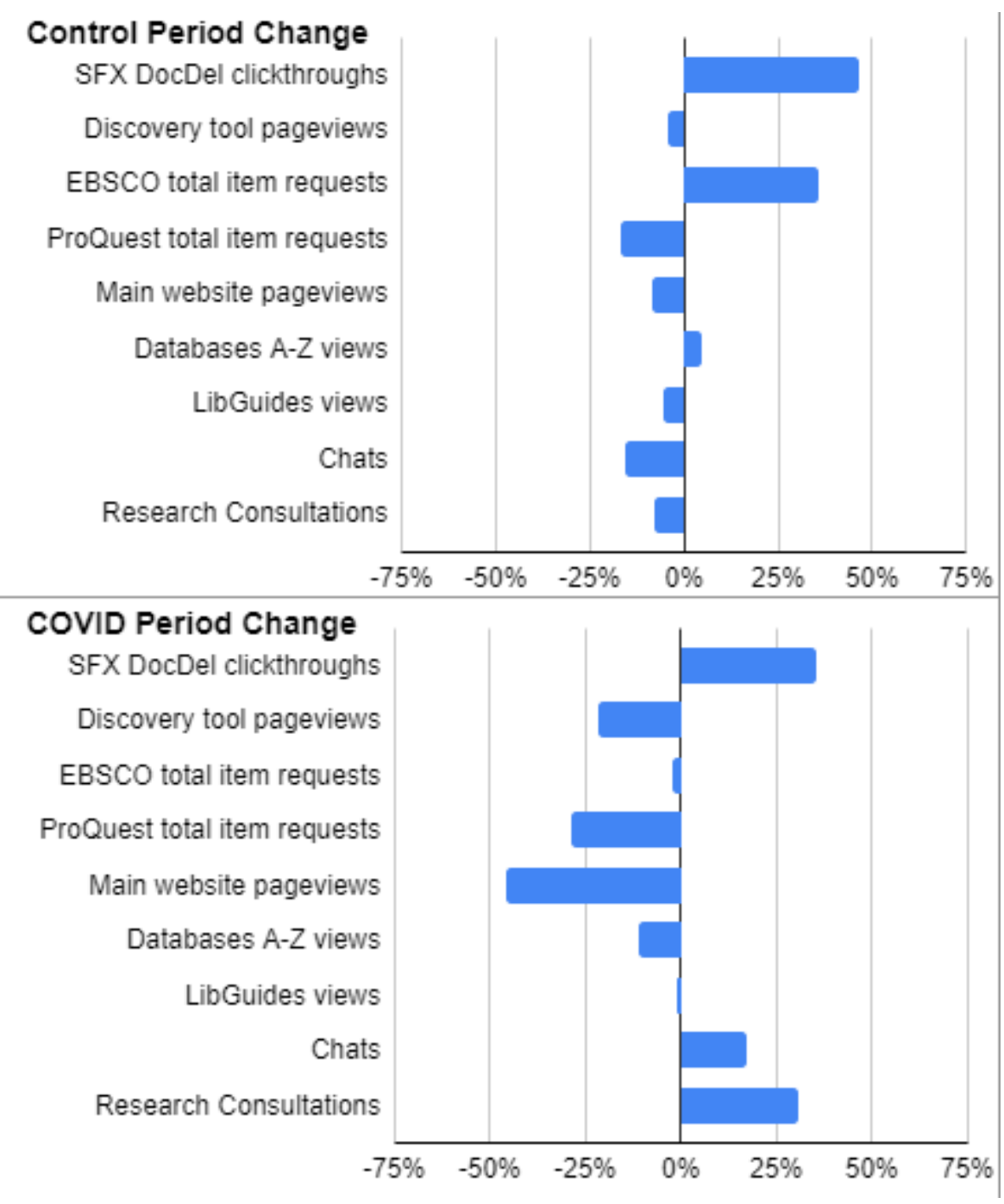

Figure 3. NEIU: Change from 2019 to 2020 in both control and COVID time frames (in \%).

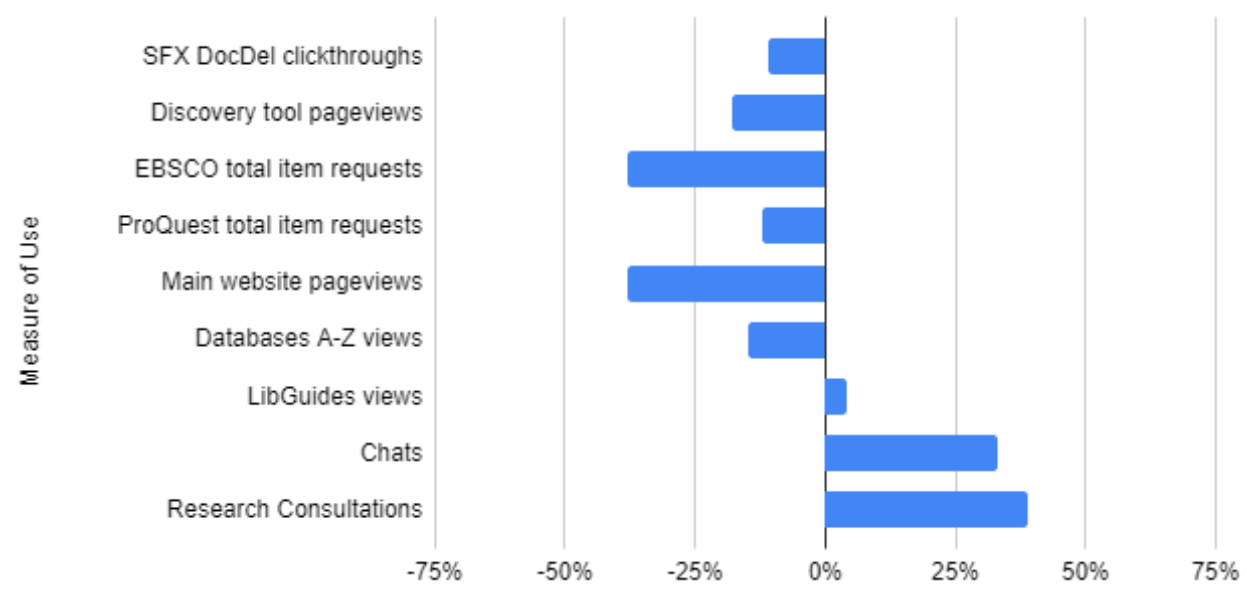

Figure 4. NEIU: Percentage of differences in COVID time frames from determined baselines. 


\section{Valparaiso University}

Overall, usage of Valparaiso University's library resources dropped dramatically during the part of the 2020 spring semester affected by COVID-19 (see table 4). Reductions occurred in all areas except chat assistance. If you consider that usage was up in most categories during the pre-COVID19 part of the semester compared to the previous year, the decline during the latter part of the semester is even more significant. The two exceptions to this pattern of COVID-related net reduction were chat questions and interlibrary loan lending requests received (see figure 6).

Table 4. Valpo: Use of library resources during control and COVID time frames, 2019 and 2020

\begin{tabular}{|l|l|l|l|l|l|l|}
\hline \multicolumn{1}{|c|}{ Measure of use } & \multicolumn{1}{|c|}{$\begin{array}{c}\mathbf{2 0 1 9} \\
\text { control }\end{array}$} & \multicolumn{1}{|c|}{$\begin{array}{c}\mathbf{2 0 2 0} \\
\text { control }\end{array}$} & $\begin{array}{c}\text { Control } \\
\text { time } \\
\text { frame } \\
\text { change }\end{array}$ & $\begin{array}{c}\mathbf{2 0 1 9} \\
\text { COVID }\end{array}$ & $\begin{array}{c}\mathbf{2 0 2 0} \\
\text { COVID }\end{array}$ & $\begin{array}{c}\text { COVID } \\
\text { time } \\
\text { frame } \\
\text { change }\end{array}$ \\
\hline $\begin{array}{l}\text { ILL borrowing \& } \\
\text { DocDel }\end{array}$ & 564 & 668 & $18 \% \Delta$ & 721 & 622 & $-14 \% \nabla$ \\
\hline ILL lending & 341 & 260 & $-24 \% \nabla$ & 373 & 303 & $-19 \% \nabla$ \\
\hline Catalog pageviews & 18,951 & 16,231 & $-14 \% \nabla$ & 26,865 & 6,234 & $-77 \% \nabla$ \\
\hline $\begin{array}{l}\text { Discovery tool } \\
\text { pageviews }\end{array}$ & 20,020 & 21,369 & $7 \% \Delta$ & 32,818 & 28,534 & $-13 \% \nabla$ \\
\hline $\begin{array}{l}\text { EBSCO total item } \\
\text { requests }\end{array}$ & 7,355 & 7,324 & $-0 \% \nabla$ & 10,871 & 10,159 & $-7 \% \nabla$ \\
\hline $\begin{array}{l}\text { ProQuest total item } \\
\text { requests }\end{array}$ & 8,770 & 10,844 & $24 \% \Delta$ & 12,325 & 10,915 & $-11 \% \nabla$ \\
\hline $\begin{array}{l}\text { Main website } \\
\text { pageviews }\end{array}$ & 27,334 & 31,919 & $17 \% \Delta$ & 29,771 & 21,336 & $-28 \% \nabla$ \\
\hline $\begin{array}{l}\text { Databases A-Z } \\
\text { views }\end{array}$ & 3,959 & 4,242 & $7 \% \Delta$ & 5,044 & 4,526 & $-10 \% \nabla$ \\
\hline LibGuides views & 15,395 & 18,029 & $17 \% \Delta$ & 13,374 & 12,980 & $-3 \% \nabla$ \\
\hline Chats & 26 & 32 & $23 \% \Delta$ & 20 & 37 & $85 \% \Delta$ \\
\hline
\end{tabular}




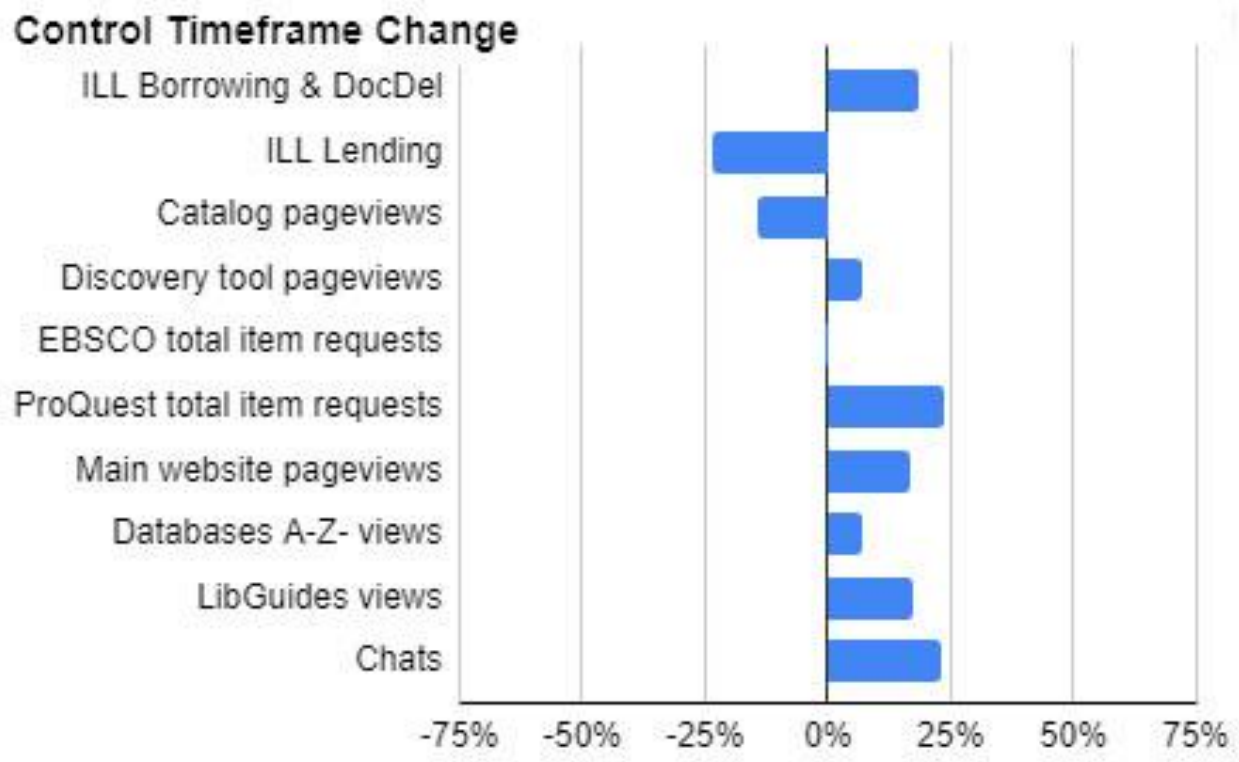

COVID Timeframe Change

ILL Borrowing \& DocDel

ILL Lending

Catalog pageviews

Discovery tool pageviews

EBSCO total item requests

ProQuest total item requests

Main website pageviews

Databases A-Z- views

LibGuides views

Chats

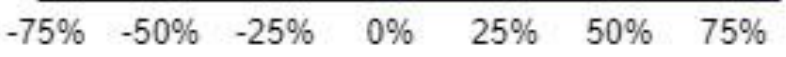

Figure 5. Valpo: Change from 2019 to 2020 in both control and COVID time frames (in \%).

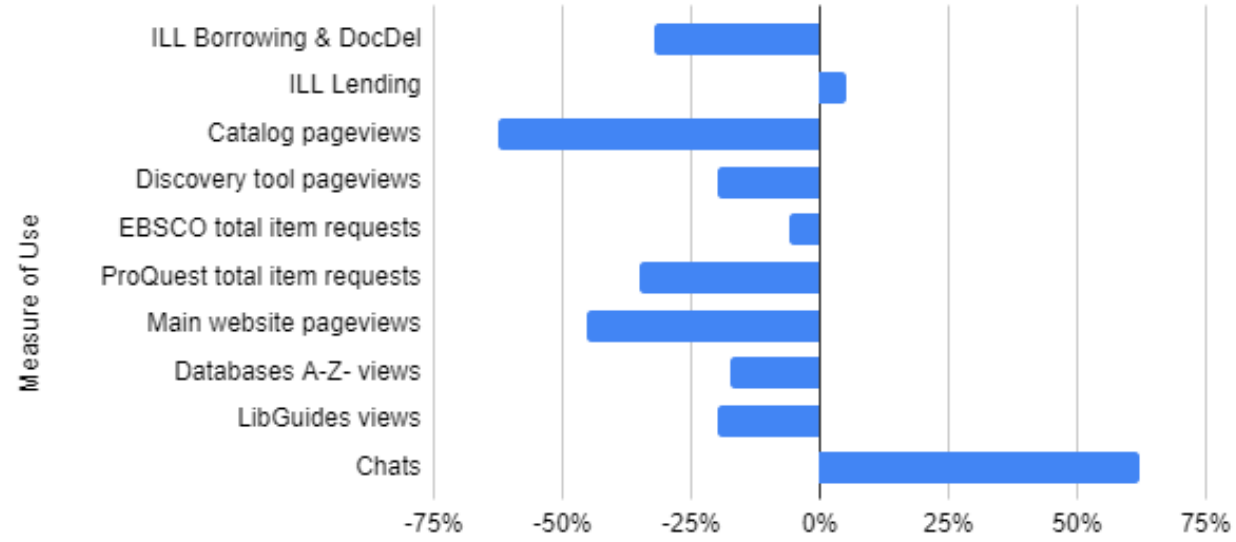

Figure 6. Valpo: Percentage of differences in COVID time frames from determined baselines. 
Table 5. Three institutions: Net pandemic change in resource use (in \%)

\begin{tabular}{|l|l|l|l|}
\hline Measure of use & LSU & NEIU & Valpo \\
\hline ILL borrowing \& DocDel & $37 \% \boldsymbol{\Delta}$ & & $-32 \% \boldsymbol{\nabla}$ \\
\hline ILL lending & $66 \% \boldsymbol{\Delta}$ & & $5 \% \boldsymbol{\Delta}$ \\
\hline SFX DocDel clickthroughs & & $-11 \% \boldsymbol{\nabla}$ & \\
\hline Catalog pageviews & $-20 \% \boldsymbol{\nabla}$ & & $-62 \% \boldsymbol{\nabla}$ \\
\hline Discovery tool pageviews & $-11 \% \boldsymbol{\nabla}$ & $-18 \% \boldsymbol{\nabla}$ & $-20 \% \boldsymbol{\nabla}$ \\
\hline EBSCO total item requests & $-6 \% \boldsymbol{\nabla}$ & $-38 \% \boldsymbol{\nabla}$ & $-6 \% \boldsymbol{\nabla}$ \\
\hline ProQuest total item requests & $-153 \% \boldsymbol{\nabla}$ & $-12 \% \boldsymbol{\nabla}$ & $-35 \% \boldsymbol{\nabla}$ \\
\hline Main website pageviews & $-13 \% \boldsymbol{\nabla}$ & $-38 \% \boldsymbol{\nabla}$ & $-45 \% \boldsymbol{\nabla}$ \\
\hline Databases A-Z views & $1 \% \boldsymbol{\Delta}$ & $-15 \% \boldsymbol{\nabla}$ & $-17 \% \boldsymbol{\nabla}$ \\
\hline LibGuides views & $58 \% \boldsymbol{\Delta}$ & $4 \% \boldsymbol{\Delta}$ & $-20 \% \boldsymbol{\nabla}$ \\
\hline Chats & & $33 \% \boldsymbol{\Delta}$ & $62 \% \boldsymbol{\Delta}$ \\
\hline Research consultations & & $39 \% \boldsymbol{\Delta}$ & \\
\hline Ask-a-Librarian tickets & $384 \% \boldsymbol{\Delta}$ & & \\
\hline
\end{tabular}

\section{DISCUSSION}

\section{Louisiana State University}

Usage of the libraries' website, discovery system, and catalog all declined during the COVIDenforced closure. Use of the main library site has been steadily declining since 2012. LSU Library's main website saw reduced traffic in both 2020 time frames, but this reduction was particularly dramatic during the COVID-19 pandemic. Catalog use has also been declining but experienced a sharp decline of $25 \%$ during the COVID closure. Catalog use regularly drops when the library is closed, at least partially owing to the fact that library staff are heavy catalog users. Also, the catalog is largely used by patrons seeking print items and, with the closure of the library building, patrons were less likely to search for print items. Therefore, a drop could be expected, but such an extreme reduction was a surprise. Usage of the main discovery system (EDS) followed a similar trajectory. As most discovery searches begin on the library website's home page, a decline in discovery use would logically follow a decline in website usage. EDS pageviews declined between 2019 and 2020 during the control time frame by $6 \%$ but declined much more sharply during the COVID time frame.

Interlibrary Loan requests (borrowing/document delivery and lending) rose considerably during the closure. One factor in the borrowing/document delivery increase was that document delivery was opened up to undergraduates during the COVID 2020 time frame; this service was not available to that patron group during the control time frames and the COVID 2019 time frame.

Downloads through EBSCO, typically LSU's busiest platform, increased in both the control time frame (37\%) and COVID time frame (30\%), resulting in a baseline-factored decrease of $6 \%$ (rounded to the nearest percent). ProQuest use was less straightforward to interpret. While there was a dramatic decrease in downloads between 2019 and 2020, that seems to owe more to an unusually high usage in the 2019 COVID time frame rather than a precipitous drop in the 2020 COVID time frame. 
LSU uses Springshare's popular LibGuides product, both for its list of databases (Databases A-Z) and as a platform for research guides. Usage of the Databases A-Z page was minimally impacted in the COVID time frame. However, overall guide usage rose significantly at $56 \%$. At least some of this is due to the creation of a COVID-specific research guide. This guide included descriptions and links to various electronic resources which vendors had made freely available during the crisis. That page alone had nearly 1,700 views in the COVID time frame. But other pages with no clear connection to COVID also had significant increases. This may reflect students feeling the need to consult electronic guides to compensate for lack of in-person access to librarians.

The COVID closure did have an enormous impact on usage of LSU's patron support system. This system, labeled "Ask Us!", handled 108 tickets in the 2020 COVID time frame, compared to 17 in 2019. While this system's use was trending upward in the control time frame as well, the jump in use during the COVID-19 closure was notable. While many of the tickets were similar to questions asked when the libraries were open, many others were clearly related to the library's closure. For example, several inquiries were in reference to alternate access to print items (such as scanning and delivering electronic versions of book chapters). There were also inquiries about when the building might reopen, and when patrons might be able to access print items that had been placed on hold.

\section{Northeastern Illinois University}

The library's website is part of the university's Drupal content management system, which restricts the library's ability to design and structure content. For that reason, much of the high impact library content is stored on third-party sites, like LibGuides or WorldCat Discovery. While the library directs users to start their research on the main website, users typically immediately follow a link that leads them to one of those third-party resources. Usage of the library website and resources linked from the website both dropped.

SFX document delivery clickthroughs, which pass users through to NEIU's interlibrary loan request pages, saw increases overall in 2020 compared to 2019. This is not surprising, given that NEIU was forced to cancel two "big deal" packages at the end of 2019.

The NEIU Libraries' chat service was one of the resources that experienced increased usage during the COVID 2020 time frame. An informal review of questions coming in during the early COVID closure showed that most respondents were asking about building hours or returning or checking out materials. While the library website was immediately updated with COVID-related closure information, the chat button is easily spotted and readily available, while the hours and materials information required clicking additional links. Research consultations also increased. As the physical reference desk was no longer available, students and faculty were directed to use email or set up subject librarian Google Meet appointments for those questions where they may have usually visited the desk. An increase of $31 \%$ in these interactions demonstrates that users still needed librarian assistance with research and course-related questions in the time of COVID.

\section{Valparaiso University}

When evaluating Valpo's interlibrary loan demand, only article requests (for both borrowing/document delivery and lending) were considered; loans were excluded. Demand from Valpo patrons fell $32 \%$ during the time frame affected by COVID-19. Despite lack of access to the print collection once the pandemic hit, net lending demand from electronic resources rose slightly. 
Catalog use was in decline before COVID hit. This is likely due to the increased reliance on the library's discovery tool, which includes records for all materials held in the catalog. However, the difference in use seen during the pandemic is striking; net use fell $62 \%$. Because patrons use the catalog to access information about the library's physical collection and the library was closed, this precipitous decline is not surprising. Overall discovery tool (Summon) use also fell during the 2020 COVID time frame (20\%).

Valparaiso University subscribes to approximately 60 EBSCO databases and 30 ProQuest databases, making them Valpo's most popular database vendors. Both saw declines, but in ProQuest more than EBSCO.

The library's main website has slightly more than 100 pages, and although it serves as a starting point to reach many of the library's other resources on different platforms (databases, LibGuides, etc.) it still receives considerable use: 147,125 pageviews in the 2019 calendar year. High-use pages include hours, the library directory, departments such as Interlibrary Loan and Archives \& Special Collections, and the listing of liaison librarians. The main website experienced a net $45 \%$ drop during the time frame affected by COVID-19.

Valpo uses LibGuides for two primary purposes: to organize and share approximately 200 databases using the product's A-Z Database List, and to deliver subject-specific and instruction content. The A-Z lists are heavily used by students and faculty across campus. However, during the pandemic, net usage of the databases fell 17\%. The net decrease in LibGuides views was approximately the same at $-20 \%$.

Seemingly, patrons had increased need for chat reference during the pandemic, although Valpo receives a relatively small number of chat questions. During the first part of the spring 2020 semester unaffected by COVID, Valpo received six more questions over the same time frame in 2019. During the COVID-affected part of the 2020 semester, usage jumped from 20 chats to 37 chats. Again, these numbers are small, so caution should be used in interpretation, but considering the baseline change from the control time frame, there was a net $62 \%$ jump in usage for chat reference during the COVID time frame.

\section{Commonalities and Trends}

While the study did not set out to compare usage among the three institutions, some clear patterns did emerge. Use of all three libraries' websites as well as the discovery tools/catalogs and major databases decreased during the COVID time frame. A number of explanations could apply. For instance, regarding library website usage, libraries' public computers are often set to open to the libraries home pages whenever a new browser is launched. When those computers are not in use, such as when library buildings are closed, students do not automatically start their research on those pages. Even though students did continue to interact with librarians and library staff through virtual methods, in-person reference encounters were not possible during COVID. Many patron interactions begin with librarians demonstrating how to start research at the library home page, moving on to find databases or conduct searches in the discovery tool or catalog.

Without direct librarian guidance, it is not surprising that students do not start their research at library tools. Whether it is because they do not realize library resources are available off campus or they have become fond of free web search tools such as Google Scholar, most public services librarians would expect a decrease in library resource usage when students are not on campus. 
With the exception of LSU's LibGuides usage, the results of this study do not support the ALA assertion that COVID led to "leaps in the use of digital content" by library patrons.

It is not surprising to see that all three libraries experienced an increase in virtual communication methods, as chat, email, and online meetings were the only means of student-librarian communication once campuses closed. No longer could students catch library staff in the stacks or at a service desk to ask quick-and often uncounted-questions. Instead, interactions were more easily measured through the virtual trails they left behind. It would be difficult to determine whether overall student-librarian interaction increased or decreased during the COVID time frame as compared to "normal" times. Data only show that students did continue to seek help from libraries even when the buildings were closed.

Individual institutions noted some within-time frame usage patterns. For instance, Valpo found that the drop in usage was more dramatic during the first part of the COVID 2020 time frame and improved during the latter part of the COVID time frame. Initially, students were probably in sinkor-swim mode, with school assignments having a lower priority in their lives. After the first month or so, students and faculty may have been able to start thinking about research needs more.

Valparaiso University fared the worst of the three institutions, with net decreases in eight out of ten of the areas studied (80\%) (see table 4). NEIU had decreases in six out of nine areas (67\%) and LSU, the largest institution, broke even with five out of ten (50\%) areas showing decreases. Valpo has a Carnegie classification of highly residential, while LSU and NEIU are primarily nonresidential. It could be that the residential nature of Valpo's campus more negatively impacted use when students were away from campus. LSU, a state flagship, has a higher percentage of graduate students than Valpo or NEIU. It seems likely that graduate students would be more determined to continue research activities during the closure than undergraduates, which may explain the smaller decrease. This could be an area of further research.

\section{CONCLUSION}

As the pandemic continues and universities plan for altered learning environments into the fall, will there be a rebound in library system and resource usage, or will the dramatic dip seen during immediate COVID time frame continue? Nearly every day there are multiple webinars for academic libraries, their administrators, and their staff members to share their stories, compare their experiences, and help guide each other for operating in the new normal. Librarians have had time to adjust typical pedagogical practices, learn new virtual technologies, and develop outreach plans to ensure continued library instruction in remote and online environments. Other changes to library practice may include an even greater shift in acquisitions from print to electronic resources. Services for distance students might become a greater point of emphasis. Faculty, too, have had time to reevaluate their syllabi and identify support needs for themselves and their students as courses go online. As with so many areas of life these days, the outcomes of this work remain uncertain. 


\section{ENDNOTES}

1 “COVID-19 Map,” Johns Hopkins Coronavirus Resource Center, accessed July 31, 2020, https://coronavirus.jhu.edu/map.html.

2 The Carnegie Classification of Institutions of Higher Education, 2018 ed. (Bloomington: Indiana University Center for Postsecondary Research, 2018), https://carnegieclassifications.iu.edu/.

3 The Carnegie Classification.

4 “Library Collection by Material Type: Fiscal Year 2018," National Center for Education Statistics, accessed August 21, 2020, https://nces.ed.gov/ipeds/datacenter/InstitutionByName.aspx?goToReportId=1.

${ }^{5}$ The Carnegie Classification.

6 "Library Collection by Material Type."

7 “Enrollment Data by Semester," Valparaiso University Office of Institutional Effectiveness, accessed August 11, 2020, https://www.valpo.edu/institutional-effectiveness/institutionalresearch/enrollment-data/.

8 "Library Collection by Material Type."

9 S. D. Allen Iske and Linda G. Lengfellner, "Fire, Water \& Books: Disaster Preparedness for Academic Libraries," Professional Safety 60, no. 10 (October 2015), https://search.proquest.com/docview/1735009821?pq-origsite=summon; Daryl L. Superio, Stephen B. Alayon, and Mary Grace H. Oliveros, "Disaster Management Practices of Academic Libraries in Panay Island, Philippines: Lessons from Typhoon Haiyan," Information Development 35, no. 1 (January 2019): 51-66, https://doi.org/10.1177/0266666917725905; Andy Corrigan, "Disaster: Response and Recovery at a Major Research Library in New Orleans," Library Management 29, no. 4/5 (May 2008): 293-306, https://doi.org/10.1108/01435120810869084.

${ }^{10}$ Lisa McGuire, "Planning for a Pandemic Influenza Outbreak: Roles for Librarian Liaisons in Emergency Delivery of Educational Programs," Medical Reference Services Quarterly 26, no. 4 (December 2007): 1-13, https://doi.org/10.1300/】115v26n04 01.

${ }^{11}$ Bradley P. Tolppanen and Marlene Slough, "Providing Circulation Services in a Temporary Location," Journal of Access Services 1, no. 4 (May 24, 2004): 125, https://doi.org/10.1300/J204v01n04 10.

12 Walter M. Fontane, "Assessing Library Services during a Renovation," Journal of Access Services 13, no. 4 (October 1, 2016): 223, https://doi.org/10.1080/15367967.2016.1250643.

${ }^{13}$ Fontane, 223.

${ }^{14}$ Marc Vinyard et al., "A Pop-up Service Point and Repurposed Study Spaces: Maintaining Market Share During a Renovation," Journal of Library Administration 58, no. 5 (July 4, 2018): 449-67, https://doi.org/10.1080/01930826.2018.1468193. 
${ }^{15}$ Amy Harmon, "Inside the Race to Contain America's First Coronavirus Case," New York Times, February 5, 2020, sec. US, https://www.nytimes.com/2020/02/05/us/corona-viruswashington-state.html; Karin Fischer, "Colleges Brace for More-Widespread Outbreak of Coronavirus," Chronicle of Higher Education, February 26, 2020, http://www.chronicle.com/article/Colleges-Brace-for/248123.

16 "Guidance for Interruptions of Study Related to Coronavirus (COVID-19)," US Department of Education Office of Postsecondary Education, updated June 16, 2020, https://ifap.ed.gov/electronicannouncements/030520Guidance4interruptionsrelated2CoronavirusCOVID19.

17 "Libraries Respond: COVID-19 Survey Results (May 2020)," American Library Association, http://www.ala.org/tools/covid/libraries-respond-covid-19-survey.

18 "Libraries Respond: COVID-19 Survey," Appendix 1: Academic Library Financial Aggregate Tables.

19 "Survey: Libraries Examine Phased Building Re-Opening, Prepare Summer Programs," American Library Association News and Press Center, June 3, 2020, http://www.ala.org/news/pressreleases/2020/06/survey-libraries-examine-phased-building-re-opening-prepare-summerprograms.

20 "Libraries Respond: COVID-19 Survey" (instrument), American Library Association, May 2020, http://www.ala.org/pla/sites/ala.org.pla/files/content/advocacy/covid-19/LibrariesRespond-COVID-19-Survey-May-2020 5-12-20.pdf.

${ }^{21}$ Karin Fischer, "As Coronavirus Spreads, Colleges Make Limited Allowances for Support Staff," Chronicle of Higher Education, March 23, 2020, http://www.chronicle.com/article/AsCoronavirus-Spreads/248304.

${ }^{22}$ Christine Wolff-Eisenberg and Lisa Janicke Hinchliffe, "Academic Library Strategies Shift to Closure and Restriction," Ithaka S+R (blog), March 15, 2020, https://sr.ithaka.org/blog/academic-library-strategies-shift-to-closure-and-restriction/.

${ }^{23}$ Fischer, "As Coronavirus Spreads"; Colleen Flaherty, "Librarians Advocate Closing Campus Libraries during Coronavirus Pandemic," Inside Higher Ed, March 19, 2020 , https://www.insidehighered.com/news/2020/03/19/librarians-advocate-closing-campuslibraries-during-coronavirus-pandemic.

24 "Cloud-Based Library Platform Keeps California Community College Libraries Operational during COVID-19 Crisis-System Is Now Live at 110 California Community Colleges," Library Technology Guides, Current News Service and Archive, 2020, https://librarytechnology.org/pr/25004; "Springshare Responds to Remarkable Shift to Online Library Services," Library Technology Guides, Current News Service and Archive, April 29, 2020, https://librarytechnology.org/pr/25116.

25 "Statement on the Global COVID-19 Pandemic and Its Impact on Library Services and Resources | ICOLC Website," ICOLC Coordinating Committee, March 13, 2020, 
https://icolc.net/statement/statement-global-covid-19-pandemic-and-its-impact-libraryservices-and-resources.

26 "ICOLC COVID19 Complimentary Expanded Access Specifics" (Google Doc), accessed May 8, 2020, https://docs.google.com/spreadsheets/d/1xilNlF9P00t05lGKi3v4S413iujYCm5QJoKUG19a Y/edit?usp=sharing.

27 "Libraries Without Walls: Even Wider Access to Digital Resources During Pandemic | Penn State University," Penn State News, April 8, 2020, https://news.psu.edu/story/614577/2020/04/08/research/libraries-without-walls-evenwider-access-digital-resources-during.

${ }^{28}$ Emilija Sagaityte and Cate Ryan, "Historic Pandemic Poses Lasting Impact On Libraries, Scholarship," Brown Daily Herald, March 31, 2020, https://www.browndailyherald.com/2020/03/31/historic-pandemic-poses-lasting-impacton-libraries-scholarship/.

29 "Message to Libraries about COUNTER Usage during the Covid-19 Pandemic," Project Counter, June 12, 2020, https://www.projectcounter.org/message-to-libraries-about-counter-usageduring-the-covid-19-pandemic/.

30 "Outmigration Numbers Increase, with Evidence of Tie to Budget Impasse," Illinois Board of Higher Education, March 12, 2019, http://www.ibhe.org/PressReleases/2019.03.12-IBHEOutmigration-Numbers-for-Web.htm.

31 "Fall Enrollments: Five-Year Trend Data," Northeastern Illinois University, accessed June 3, 2020, https://www.neiu.edu/sites/neiu.edu/files/documents/ysun2/Fall\%202019\%20Data\%20Di gest $\% 205$-year $\% 20$ Enrollment.pdf. 